Peer-Reviewed Article

ISSN: 2162-3104 Print/ ISSN: 2166-3750 Online

Volume 6, Issue 4 (2016), pp. 905-919

(C) Journal of International Students

http://jistudents.org/

\title{
Being Wholesaled: \\ An Investigation of Chinese International Students' Higher Education Experiences
}

\author{
Mengwei Su \\ Ohio University, USA \\ Laura M. Harrison \\ Ohio University, USA
}

\begin{abstract}
Using academic capitalism as a theoretical foundation, this phenomenological study examined the new study abroad experiences of Chinese college students in six popular English-speaking study destination countries-the U.S., the U.K., Australia, Canada, the Netherlands, and Singapore. Qualitative data collected from 20 interviews indicate some hosting higher education institutions prioritize enrollment growth and neglect recruitment process and student development. Three main findings are 1) delegating recruitment to overseas agencies causes mismatches between host institutions and the Chinese students, 2) Chinese students having insufficient language skills are prone to have a dissatisfied study abroad experience, and 3) high density of student population from one country impedes Chinese students' integration on campus. Implications for higher educational professionals, students, and faculty are presented.
\end{abstract}

Keywords: academic capitalism, Chinese international students, student satisfaction

While the large global increase in the international student population is a significant trend, it is rarely discussed in the contexts of its economic origins and its impact on students. According to International Consultants for Education and Fairs (ICEF) data released in 2015, the total number of international students surpassed 5 million in 2014, which more than doubled and tripled the numbers in 2000 and 1990, respectively ('The state of 
international student mobility in 2015', 2015). While university officials cite other motivations for encouraging international student growth (such as global awareness and diversity), some scholars worry the impetus for recruiting these students is largely financial (Choudaha et al., 2013; Matthews \& Lawley, 2011; Ross, Grace, \& Shao, 2013; Thomason, 2013). For instance, as the largest hosting country for international students, the U.S. received \$30.8 billion through exports of higher education in 2015 (John Siegmund, Barb Rawdon, \& Clara Ren, 2016). International students present an attractive market for cash-strapped universities seeking students who will pay the higher out of state tuition rate, generally without financial aid. While higher education institutions can and should take care of their bottom line, how does the profit motive affect universities' treatment of students some worry are increasingly viewed as "cash cows" (Cantwell, 2015)?

The global financial crisis in 2007 swept across North America and European Union countries, causing many of those developed countries to cut their government funding to higher education. In the U.S., state fiscal support for higher education from FY2008 to FY2013 has decreased by 10.8\% (Zumeta, 2013, p. 32). In Canada, government funding to university operating budgets dropped from $84 \%$ to $58 \%$ in the last thirty years (Ivanova, 2013). In the U.K., the British government announced in 2010 a $40 \%$ cut in funding to higher education over a five-year period between 2010 and 2015 (European University Association, 2011). In the same year, the Australia common wealth government ceased its commitment to increase expenditure in higher education; instead, it announced in 2013 a plan to reduce AU\$ 2.3 billion funding over a four-year period, the largest budget cut to higher education since 1996 (Jump, 2013). In order to survive such an austere financial climate, higher education institutions in these four countries simultaneously shifted their cost to the students. International students are viewed as a key part of the solution because they pay tuition at a higher rate than domestic students.

China is a particularly lucrative market for international students. According to the United Nations Educational, Scientific and Cultural Organization (UNESCO), China accounted for $17 \%$ of the world's international students in 2013, sending 712,157 young people abroad for higher education ('Global flow of tertiary-level students', 2016). The top four English-speaking destination countries that Chinese international students choose are the U.S., the U.K., Australia, and Canada. The United States hosted over a quarter of million Chinese college students in 2014, more than the U.K, Australia, and Canada combined (2016). The majority of today's Chinese international students can afford the cost of a foreign higher education; over $95 \%$ of Chinese students studying overseas are self-funded (Choudaha et al., 2013). 
The high density of international students from one country poses both opportunities and challenges to university administrators. While universities tend to highlight the diversity Chinese students bring to campus, their overrepresentation compared to students from less developed nations suggests financial motivations play a significant if not exclusive role. Scholars have focused on either how universities tap the Chinese student market or what challenges Chinese students face, few studies connect these disparate bodies of scholarship.

\section{LITERATURE REVIEW}

Rhoads and Slaughter (2004) define academic capitalism as "a regime that entails colleges and universities engaging in market and market-like behaviors." They identify the motivation of this new institutional behavior as generating "revenue from their core educational, research, and service functions, ranging from the production of knowledge created by faculty to the faculty's curriculum and instruction” (p. 37). The two scholars concluded that U.S. higher education institutions are slowly evolving into a corporate-like enterprise that pursues monetary gains, at times eclipsing their educational mission.

Slaughter and Rhoades (2004) are particularly concerned about undergraduate students being exploited in the U.S. educational markets. Colleges and universities market themselves to undergraduate students in ways that best serve the institutions' interests. Such practices inevitably position students as consumers, as opposed to their traditional role as products of the education process (Sirvanci, 1996). Slaughter and Rhoades (2004) focus on the impact of academic capitalism on American higher education. However, today's market is a global one, not bound by institution, state, or country. Academic capitalism blurs old boundaries and expands transnationally (Hanley, 2005; Kauppinen, 2012). The overseas market appealed to not only American colleges and universities but all other Western higher education institutions in the context of the most recent financial collapse. While the escalating enrollment of Chinese students is lucrative for host higher education institutions, how their experiences are impacted is an under-examined phenomenon in the literature.

\section{RESEARCH METHOD}

The aim of this research was to understand the relationship between Chinese international students' overseas educational experiences and host higher education institutions' global attractiveness in the context of academic capitalism. We choose to use a phenomenological approach because it "describes the meaning for several individuals of their lived experiences of a 
concept of phenomenon” (Creswell, 2007, p. 57). Our participants shared the experience of being Chinese international students; our aim was to gain an in-depth understanding of what meaning they ascribed to features of their college experience they identified as significant.

Finally, we embarked on this research in hopes of uncovering data with the potential to inform higher education policy regarding international students. Phenomenological approaches are particularly well-suited for describing common experiences of complex problems. Once understood in greater depth, these experiences can provide the foundation upon which to build increasingly more well-informed policy (Creswell, 2007).

This study addressed the following research questions:

1. What institutional features do Chinese students identify as most important in impacting their experience of international higher education?

2. How do Chinese students define quality in their experiences of international higher education?

3. How can institutions of higher education create environments that offer Chinese students the best opportunity for a quality international education experience?

\section{Participants}

We selected 20 Chinese international student participants who met the following criteria: (a) Participants have had at least one year's experience of studying abroad. (b) The language used in the participants' programs of study is English. (c) Participants are self-funded students.

Half of the 20 participants are Ohio University students or recent graduates recruited by the researchers based on participants' stratified satisfaction in their educational experiences. The other half of the 20 participants selected were current or very recent graduates of non-American colleges and universities - 5 British (4 English and 1 Scottish), 2 Australian, 1 Canadian, 1 Dutch, and 1 Singaporean. Those participants were recruited from an ESL test-prep school in Shanghai to which one of the researchers had access. All participants are identified by pseudonyms.

\section{Data Collection}

The data are composed of 20 in-depth interviews (30-60 minutes) conducted with the participants either in person or via SKYPE. Interviews occurred in offices, libraries, and other campus environments reflecting the natural setting appropriate for qualitative research (Denzin \& Lincoln, 2011). We organized the questions chronologically, asking each participant to reflect on their pre-entry, in-college, and post-college experiences. We recorded each session and had each recording transcribed. We edited each 
transcript for clarity only before sending them to participants. We employed member-checking as a trustworthiness measure, returning transcripts to participants and allowing them to explain, correct and elaborate as needed. As another trustworthiness measure, we maintained a shared researchers' journal to capture non-verbal communication as well as our impressions.

\section{Table 1: QSR NVivo Data Coding Output Sample}

\begin{tabular}{|c|c|c|}
\hline In vivo & Code & Theme \\
\hline $\begin{array}{l}\text { "Actually there are } 16 \text { students in my class and half } \\
\text { of them are from China and half of them mostly } \\
\text { come from the U.K." }\end{array}$ & \multirow{4}{*}{$\begin{array}{l}\text { high } \\
\text { density of } \\
\text { Chinese } \\
\text { student } \\
\text { population }\end{array}$} & \multirow{13}{*}{$\begin{array}{l}\text { The high } \\
\text { density of } \\
\text { Chinese } \\
\text { student } \\
\text { population } \\
\text { on campus } \\
\text { becomes a } \\
\text { source for } \\
\text { isolation, } \\
\text { which } \\
\text { affects the } \\
\text { students' } \\
\text { developme } \\
\text { nt. }\end{array}$} \\
\hline $\begin{array}{l}\text { "Yeah like half (of the class are Chinese), I'd say. } \\
\text { Yeah, that's quite a lot, but yeah." }\end{array}$ & & \\
\hline $\begin{array}{l}\text { "MFE program has } 90 \% \text { of the international } \\
\text { students and most of them are from China. So the } \\
\text { class is not much different from that in our } \\
\text { country." }\end{array}$ & & \\
\hline "70\% of the students in my class are from China." & & \\
\hline $\begin{array}{l}\text { "All my class were American, only one Asian. } \\
\text { Actually, I think I'm the only Asian in the history } \\
\text { department." }\end{array}$ & \multirow{3}{*}{$\begin{array}{l}\text { low density } \\
\text { of Chinese } \\
\text { student } \\
\text { population }\end{array}$} & \\
\hline $\begin{array}{l}\text { "I am in engineering and there are not many } \\
\text { Chinese students in the engineering program." }\end{array}$ & & \\
\hline $\begin{array}{l}\text { "We don't have too many Chinese students here ... } \\
\text { I was also the only Chines student in my class." }\end{array}$ & & \\
\hline $\begin{array}{l}\text { "Somehow there would be a (Chinese) group in the } \\
\text { class: we sit together and talk to each other only." }\end{array}$ & \multirow{3}{*}{$\begin{array}{l}\text { Complaints } \\
\text { about } \\
\text { having high } \\
\text { density of } \\
\text { Chinese } \\
\text { student } \\
\text { population }\end{array}$} & \\
\hline $\begin{array}{l}\text { "We prefer a larger school which has more students } \\
\text { with different cultures and not just Chinese, you } \\
\text { know...in the U.K. most of the business schools } \\
\text { have many Chinese students. I don't prefer that." }\end{array}$ & & \\
\hline $\begin{array}{l}\text { "I think there is no difference if they study in China } \\
\text { or in the U.K. because they live with all the Chinese } \\
\text { students, play the computer games together, and go } \\
\text { to the pubs together every night." }\end{array}$ & & \\
\hline $\begin{array}{l}\text { "I join the study group because they're all } \\
\text { American students and I think I have made some } \\
\text { improvement there. It was very helpful." }\end{array}$ & \multirow{3}{*}{$\begin{array}{l}\text { Preference } \\
\text { of having } \\
\text { low density } \\
\text { of Chinese } \\
\text { student } \\
\text { population }\end{array}$} & \\
\hline $\begin{array}{l}\text { "It gives me more pressure, well, not in a bad way, } \\
\text { positive pressure to make me know more people in } \\
\text { the class" }\end{array}$ & & \\
\hline $\begin{array}{l}\text { "Yes. That was one of the reasons why I chose the } \\
\text { Netherlands rather than the U.K. or the U.S. I want } \\
\text { to avoid too many Chinese students." }\end{array}$ & & \\
\hline
\end{tabular}




\section{Data Analysis}

We used QSR NVivo 10 for qualitative data analysis in this research. After the data was transcribed and member-checked, the first step of data analysis is sorting, which involves creating a database and comparing the data with the research questions again (LeCompte, 2000; Thomas, 2006). The data were further developed into codes; there were 682 total codes, averaging 34 codes from each participant's interview.

In the process of coding, QSR NVivo 10 tracks the repetition of the codes. Themes are drawn from the repeated codes. When new codes stop emerging, this is a sign that data saturation has been reached and no additional interviews are necessary (Guest, Bunce, \& Johnson, 2006). After coding was completed and its consistency checked, we concluded the findings from the processed data.

\section{RESULTS}

\section{Application Challenges}

Findings indicate that the majority of the participants lacked sufficient knowledge and instruction in the application process. International recruitments agencies emerged as a theme in challenges participants faced as part of the application process. Over half of the participants reported they hired international recruitment agencies to facilitate their applications. However, the findings show that agencies do not always treat their clients' academic interest as their priority. Wei Ming, an undergraduate student at RMIT University in Australia, expressed his frustration with studying a major that he dislikes and told the researcher how his agent convinced him to choose it:

Wei Ming: I like art, designing, and journalism, better.

Researcher: Why are you studying Business IT if you like those?

Wei Ming: My agent told me if I study those majors, I cannot stay there after graduation. So I changed my major.

When we asked Wei Ming whether he would choose the same major if he had the chance, he firmly rejected the notion. Like Wei Ming, many other Chinese students were counseled by the international recruitment agencies to be "pragmatic," which meant letting perceived financial gain outweigh actual interest when selecting a major. Fortunately, several participants ignored this advice and prioritized academic interest. When we asked what advice they would offer future Chinese students, they all mentioned the importance of finding a right field of study. For example, Wang Hao, who studies Mechanical Engineering at McMaster University in Canada, stated, 
"When you choose a program, follow your heart. If you choose a program that you don't like, it's really hard to go through it."

Findings also reveal there are some international recruitment agencies that deliberately hide critical information from their clients. For instance, one of our participants, Qian Peng has been stuck in the English remedial class for nearly two years at Ohio University; he expressed resentment toward the agency he hired:

Before I come here, my agency told me, “Go to America, go to Ohio University, all you need to do is learning some English.” But they did not give me more information about the Ohio Program of Intensive English (OPIE). OPIE is divided into too many unnecessary levels and it is too time-consuming. Without passing OPIE, we are not allowed to register for class credits. I have a friend who has been studying OPIE for over three years now.

Qian Peng experienced a disconnect between his experience and what the agency communicated to him about the university's academic expectations. This was a theme we saw repeatedly in both our study as well as the literature on the limits of recruitment agencies.

While recruitment agencies sometimes present challenges in the application process, findings indicate students who made a college choice based on their own research tended to report higher degrees of satisfaction with their international higher education experience. For instance, Hong Chuan, an undergraduate student at Ohio University who majors in History, showed remarkable knowledge in differentiating the features between the higher education in the U.K. and the U.S., thanks to his two cousins who have already been studying in the two countries, respectively. He chose an American institution because he prefers its broad undergraduate education, which has "more diverse and more flexible courses." Hong Chuan demonstrated excellent academic records and actively participated in various social activities.

\section{Language Improvement}

Findings indicate that low language skill affected participants' experiences in significant ways. In the classroom, many participants found themselves struggling to follow the lectures, take notes, or participate in discussions. Some participants reported feeling too self-conscious to ask professors questions after class. Participants also reported language as a barrier in activities like getting a driver's license or standing up for themselves when ridiculed. Language emerged as a highly meaningful factor in determining participants' ability to navigate both academic and social challenges. 
For the Chinese students whose language skills were below par, the mandatory intensive English remedial course was frequently cited as the largest source of pain. Wang Jianhao, an undergraduate at Ohio University, described the struggle he and his fellow classmates had in OPIE:

Some of the students are very good at studies; they can pass every level. But some students are poor at studies. Either because they don't like English or they cannot focus on their studies, they fail this class. They can't move up to a higher level. They just stay there, semester by semester.

Wang Jianhao eventually gave up after one year's study at Ohio University and found a fresh start at Wilfrid Laurier University Brantford Campus in Canada.

Although, technically the duration of such programs is listed as approximately twelve weeks or one quarter/semester in most of the countries where the participants study, in reality, it is not unusual to see Chinese students who spend two school years in the program or even four years in some extreme cases. Qian Peng, who felt he was hoaxed by his agent to come to Ohio University, complained to the researchers that he was not able to go back China for two years because he had to take the language course during the school breaks. Participants reported the nonstop study of one subject and long-time separation from families at home greatly increased their stress levels. As one participant explained, "It's a waste of time and money to study English outside of China; prepare the language well at home before going abroad.”

For many Chinese students, writing is more of a daunting challenge than speaking. One participant described how he used his university's writing program to address this challenge, but added that most Chinese students did not take advantage of this opportunity: "WISER is a student support program that offers one-week courses after school that teach academic writing, critical thinking, and so on. Both undergraduate and postgraduate students can participate for free. Nevertheless, I find most of WISER participants are European students. No Chinese faces there except me." When we asked why he thought this was, he explained that many international students felt it was "brazen" to seek help for a skill they were supposed to already have.

While advice during the pre-entry process was not always helpful, the ability to access resources during their international experiences was often crucial for participants, especially with regard to language acquisition. For example, Chen Hong, a graduate student graduated from Brunel University in England, attributes her language improvement to the conversation partner she made at school. They would meet periodically and 
read newspapers together. Such opportunities of one-on-one tutoring by the local students were much valued by the Chinese international students in our study.

Navigating the differences between Chinese and Western classrooms emerged as theme related to both language struggles and triumphs. Nearly every student mentioned the transition between hierarchical nature of Chinese instruction and less formal Western teaching styles. Expectations of student participation proved confusing at first, but students generally reported positive feelings about professors who solicited their ideas in class. Participants added their appreciation for professors who slowed down class discussions to give them time to translate their thoughts before speaking, a simple, but effective technique for helping students achieve greater success in navigating this different classroom culture.

\section{Density of the Chinese Student Population}

Participants frequently cited high numbers of Chinese students on campus as a source of academic, linguistic, and social isolation from other students. Our participants who studied in England, Scotland, Singapore, and the U.S. all reported that they take classes where over $50 \%$ of the students are their compatriots. In an extreme case, $90 \%$ of the cohort at Ohio University's Master of Finance and Economics program (MFE) are Chinese. The most detrimental impact on the Chinese international students in such high density of the same population is isolation. One participant, Wang Lili had good insight on this issue because she first studied as an undergraduate student at University College Cork in Ireland in a low Chinese student density environment and then pursued graduate studies at Ohio University in a high Chinese student density. She told the researchers how she felt differently in the two universities: "[Having fewer Chinese students in classes] gave me more pressure but not in a bad way. I needed to get to know more people outside of the five Chinese in class. Having this experience makes me confident in talking here at Ohio University.”

In the English remedial program, the situation gets worse as the Chinese students almost make up the entire class. Liu Feng, another participant who went through OPIE offered his perspective on this problem:

Most of my classmates come from the same country: China and Saudi Arabia. We sometimes talk in our own languages in the class-for instance, when the instructor separates us into group discussion in the class, the Chinese students would often say Chinese to each other.

The high density of the Chinese student population impacts students' social experiences as well. It is common for Chinese students to 
choose to live with each other once they are not required to live on-campus. It is thus difficult for them to improve their English when they dwell in an environment that does not require them to practice their secondary language. Lin Xiong, a graduate student at University of Scotland, articulated this point:

Yeah, I think that's why I improve my English so slow. I don't know why but every time when I speak English to the westerners, I am not very nervous; however, when there is another Chinese student present, I would get nervous. In the winter holiday, I traveled alone in Europe for forty-six days. When I came back, my British friends said my English became very good. Now, after two months I live with my Chinese flatmates, my spoken English is terrible again.

Findings also indicate that some participants took action to deal with this conundrum either before or after matriculation. Zhao Yinyin, a graduate student at the University of Amsterdam in the Netherlands, chose to study in the Netherlands because she heard from a classmate that Chinese students were overrepresented in many U.K. and U.S. universities. Ma Dong, a graduate student at Ohio University, deliberately joined a study group that was entirely made up of local students. Pan Jing attributed her successful transition to studying in the U.S. to finding her American roommate, who studied Linguistics and enjoyed talking with an ESL learner. Participants were sometimes able to negotiate the linguistic and social isolation they felt when surrounded by other Chinese students, but they generally had to be pro-active in order to do so successfully.

\section{DISCUSSION}

The researchers set out to investigate what factors affect the "customer experience" of the Chinese international students around the world through the lenses of academic capitalism. The results support Slaughter and Rhoades's finding (2004) that under a regime of academic capitalism, students are targeted as revenue generators and are not always well-served by that ethos. Students and parents who have little information about international higher education often resort to the international recruitment agencies and take their professional advice seriously. But the reality is that the advice they receive from agencies is often not as reliable as they might imagine. Conflicts of interest most likely account for much of the problem. Normally, a recruitment agency should represent either the colleges or the students, depending who is paying for the service. Unfortunately, Chinese students' status as a lucrative market has created a conflict of interest 
wherein less scrupulous recruiters steer students toward institutions based on the agencies' potential financial gains rather than the students' best interest. This would not necessarily be a problem if only the universities were paying the agencies' fees and there was transparency about whose interests were being served. However, if students are paying the fees, they ought to be advised based on their interests', not the universities' .

This issue is exacerbated by the fact that there are no global or national regulatory organizations to provide an industry norm by which international recruitment agencies must abide. Some countries, such as Australia and the U.K., are increasing penalties for institutions that do not properly vet these agencies. Measures like this may be an important first step in promoting oversight and consumer protection for students who use recruitment agencies.

Negative consequences for international students with regard to ESL programs may also be related to the rise in policies, practices, and procedures informed by academic capitalism. As higher education institutions around the world are all competing for Chinese international students, institutions sometimes have to choose between tuition revenue and institution's academic rigor. In the end, the enrollment pressure has caused many higher education institutions in the popular destination countries among the Chinese students to lower their admission standards and admit applicants who have not yet met the language requirement. A common practice among some colleges and universities to cope with these large numbers of less qualified recruits is to detain them in English remedial courses either operated by the institutions themselves or the outsourced contractors. By doing so, institutions further expand Chinese students' consumption by charging additional tuition and fees. Consequently, institutions do not have the urgency to push the students in the English remedial course to graduate in a timely fashion. From our research, we conclude that the longer the Chinese international students struggle in this kind of course, the less they are satisfied with their study abroad experience.

Compared with the need for English language improvement, Chinese international students' demand for a campus environment that is conducive for cultural learning only emerged recently. In the past, the Chinese student population of any Western higher education institution was much smaller than it is today. Academic capitalism has encouraged a dramatic increase of Chinese students' enrollment in many Western colleges and universities. Rose-Redwood and Rose-Redwood (2013) provide important scholarship on this point. The researchers established a social interaction continuum model of international student experiences. Under this model, many Chinese students can be recognized as "Social Segregators," that is, those students who "socially interact only with conationals, excluding other nationals and host nationals" (419), because the majority of 
the population in their classroom and residence is Chinese. Institutions that have high enrollments of Chinese international students must be aware of how significant this newly emerged issue of on-campus segregation is. This research indicates that for some Chinese international students, the density of the Chinese student population in a foreign higher educational institution has become a criterion for making a college choice.

\section{IMPLICATIONS}

Higher education institutions must take the initiative in communicating with future students rather than leaving that responsibility to profit-driven international recruitment agencies. Today, the Internet has brought the world closer than ever. Hiring international agencies is not the only option to reduce the cost of recruiting international students from overseas markets. It is recommended that any institution that expects a large Chinese student enrollment should at least have a Chinese translated web page to explain the institution's admission requirement and application procedure so that potential students and their parents could access the information directly. This research finds that when choosing a college, Chinese applicants and parents are particularly concerned about a country's immigration policy, institutional ranking, and job placement. Although the majority of the Chinese students return home after graduation, many of them have the desire to find a job in the country where they have studied and lived.

Reaching out to the Chinese applicants also involves helping the applicants explore their own academic interests and find the right programs before enrollment. The Chinese educational system is known for its articulation of competition rather than interest cultivation. Chinese parents typically have little knowledge of foreign higher education curricula and their links to career paths. Therefore, it is not surprising to see the statistics that a dominant majority of Chinese undergraduate students choose business-related majors for their overseas higher education. Institutions ought to reach out to Chinese parents and students, informing them of their abundant choices, preferably in their own language instead merely displaying the program information on the websites.

An important finding of this research is that Chinese international students' success is closely linked to their motivation. Those who do not volunteer but are pressured or even forced to study abroad have a high risk of failure. They are often not committed to studying and isolate themselves from the campus life. Therefore, colleges and universities concerned about retention and completion rates of international students should make efforts to attract self-motivated applicants.

Colleges and universities that have experienced a large increase of Chinese international student enrollment should make efforts to address the isolation caused by the high density of one ethnic group among the student 
population. On the academic front, institutions could "dilute" the density by encouraging Chinese students to take different majors. In order to achieve this goal, institutions must take measures to educate future Chinese applicants and their parents, giving them more thorough knowledge about less popular majors. In terms of the social aspects of college life, institutions could purposefully assign Chinese freshmen to a diverse living environment. Like other students, Chinese students may need encouragement from the institution to stretch out of their comfort zones. Findings from the current study suggest greater social integration plays an important role in Chinese students' ability to learn English and succeed academically as well. By addressing admissions, socialization, and academic needs holistically, institutions improve their chances of serving Chinese students more effectively.

\section{CONCLUSION}

Academic capitalism connects higher education institutions around the world in one global market. As public sector investment in higher education declines, many Western institutions have courted Chinese students as new revenue sources. The increase in Chinese students has not always been managed thoughtfully, however, as observed in challenges with both international recruitment agencies and campuses where the Chinese population has reached such high numbers that it becomes difficult for these students to have a truly international experience. The current study's findings include linguistic and social segregation as barriers to a quality international education for Chinese students. To ameliorate these problems, institutions could communicate more clearly and directly with students and parents in the pre-entry process so they could avoid the misinformation that often comes from recruitment agencies. This communication could also help students better assess their motivation for study abroad and choose more carefully as a result. Once on campus, university officials could reduce academic and social isolation by assigning students to a broader range of housing. While the consumer ethos may incline some administrators to let students choose their residence, many excellent universities like Stanford place students in the housing to maximize opportunities for diverse living environments. Perhaps ironically, it may be necessary to challenge academic capitalist values like consumer choice for universities to effectively meet the needs presented by a greater influx of Chinese students. The universities that fail to adapt to Chinese students' needs for more integrated language, academic and social opportunities will likely lose them to higher education institutions that respond more effectively to their concerns. 


\section{REFERENCES}

Cantwell, B. (2015). Are international students cash cows? Examining the relationship between new international undergraduate enrollments and institutional revenue at public colleges and universities in the U.S. Journal of International Students, 5(4), 512-525.

Choudaha, R., Li, C., \& Kono, Y. (2013). International student mobility trends 2013: Towards responsive recruitment strategies. World Education Services. Retrieved from http://wenr.wes.org/2013/03/wenr-march-2013international-student-mobility-trends-2013-towards-responsiverecruitment-strategies/

Creswell, J. W. (2007). Qualitative inquiry \& research design: Choosing among five approaches. Thousand Oaks, CA: Sage.

Denzin, N. K., \& Lincoln, Y. S. (2011). The Sage handbook of qualitative research. Thousand Oaks, CA: Sage.

European University Association. (2011). Impact of the economic crisis on European universities. Retrieved from http://www.eua.be/Libraries/Newsletter/Economic_monitoringJanuary201 1final.sflb.ashx

Global flow of tertiary-level students. (2016, October 5). Retrieved from http://www.uis.unesco.org/Education/Pages/international-student-flowviz.aspx

Guest, G., Bunce, A., \& Johnson, L. (2006). How many interviews are enough? An experiment with data saturation and variability. Field Methods, 18(1), 5982.

Hanley, L. (2005). Academic capitalism in the new university. Radical Teacher, (73), 3-7.

Ivanova, I. (2013). Time to rethink the way we fund higher education. Our Schools / Our Selves, 22(2), 143-147.

John Siegmund, Barb Rawdon, \& Clara Ren. (2016). 2016 ITA education top markets report. International Trade Administration. Retrieved from http://trade.gov/topmarkets/pdf/Education_Top_Markets_Report.pdf

Jump, P. (2013, April 16). Australian higher education hit by large funding cut. Retrieved from http://www.timeshighereducation.co.uk/news/australianhigher-education-hit-by-large-funding-cut/2003207.article

Kauppinen, I. (2012). Towards transnational academic capitalism. Higher Education, 64(4), 543-556. https://doi.org/10.1007/s10734-012-9511-x

LeCompte, M. D. (2000). Analyzing qualitative data. Theory into Practice, 39(3), 146-154. https://doi.org/10.1207/s15430421tip3903_5

Matthews, J., \& Lawley, M. (2011). Student satisfaction, teacher internships, and the case for a critical approach to international education. Discourse: Studies in the Cultural Politics of Education, 32(5), 687-698. https://doi.org/10.1080/01596306.2011.620752

Rhoades, G., \& Slaughter, S. (2004). Academic Capitalism in the New Economy: Challenges and Choices. American Academic, 37-59.

Rose-Redwood, C. R., \& Rose-Redwood, R. S. (2013). Self-Segregation or global mixing? Social interactions and the international student experience. Journal of College Student Development, 54(4), 419. 
Ross, M., Grace, D., \& Shao, W. (2013). Come on higher ed ... get with the programme! A study of market orientation in international student recruitment. Educational Review, 65(2), 219-240. https://doi.org/10.1080/00131911.2012.659656

Sirvanci, M. (1996). Are students the true customers of higher education? Quality Progress, 29(10), 99-102.

Slaughter, S., \& Rhoades, G. (2004). Academic capitalism and the new economy: Markets, state, and higher education. Baltimore, MD: Johns Hopkins University Press.

The state of international student mobility in 2015. (2015, November 5). Retrieved from http://monitor.icef.com/2015/11/the-state-of-international-studentmobility-in-2015/

Thomas, D. R. (2006). A general inductive approach for analyzing qualitative evaluation data. American Journal of Evaluation, 27(2), 237-246. https://doi.org/10.1177/1098214005283748

Thomason, A. (2013, October 15). Diversity aside, international students bring a financial incentive. Retrieved from http://chronicle.com/blogs/bottomline/diversity-aside-internationalstudents-bring-a-financial-incentive/

Zumeta, W. (2013). Higher education enters a new era. The NEA 2013 Almanac of Higher Education. Retrieved from Retrieved from http://www.nea.org/assets/docs/2013_Almanac_Zumeta.pdf

MENGWEI SU is a doctoral candidate in the Department of Counseling and Higher Education and a graduate assistant in the Allen Student Advising Center at the Ohio University. His research interests include international student development and ESL learning. Email: ms306201@ohio.edu

LAURA M. HARRISON, PhD, is an Associate Professor in the Department of Counseling and Higher Education at the Ohio University. She teaches and writes on the topics of advocacy, change, and leadership in higher education. Email: harrisol@ohio.edu 